\title{
Analisis Kestabilan Sistem Linear Time Invariant (Studi Kasus Gerak Longitudinal Pesawat Terbang BWB AC 20.30)
}

\author{
Maulida Agustin ${ }^{1, \text { a) }}$ dan M Wakhid Musthofa ${ }^{1, b)}$ \\ Program Studi Matematika UIN Sunan Kalijaga Yogyakarta \\ a)email: maulida.agustin21@gmail.com \\ b) email:mwakhid_m@yahoo.com
}

\begin{abstract}
Abstrak
Analisis kestabilan sistem linear time invariant (LTI) dapat dilakukan dengan menggunakan lima macam metode, yaitu metode input-output, metode nilai eigen, linearisasi, Lyapunov, dan Routh-Hurwitz. Kelima metode tersebut akan menghasilkan analisis kestabilan yang sama. Selanjutnya metode analisis kestabilan tersebut akan diaplikasikan pada sistem gerak longitudinal pesawat terbang BWB AC 20.30 sebagai pesawat terbang tanpa awak. Gerak ini merupakan gerak dalam arah vertikal dengan gaya reaksi di bagian sumbu roll $\mathrm{X}$ dan yaw $\mathrm{Z}$ sebagai penyebabnya. Analisis kestabilan dengan menggunakan kelima metode tersebut menghasilkan kesimpulan bahwa gerak longitudinal pesawat terbang BWB AC 20.30 stabil asimtotik. Gambaran kestabilan secara geometri dilakukan dengan simulasi menggunakan MATLAB R2013a yang menghasilkan kesimpulan yang sama.
\end{abstract}

Kata kunci: kestabilan sistem LTI , gerak longitudinal, pesawat terbang BWB AC.20.30.

\begin{abstract}
The Stability of linear time invariant (LTI) system can be analized using five different methods, namely eigen value method, Routh-Hurwitz, Lyapunov, linearization, and input-output method. These five methods will result in the same stability analysis. Furthermore, the five stability analysis methods will be applied to the longitudinal motion system of BWB AC 20.30 aircraft as one of an unmanned aircraft vehicle (UAV). This motion is a vertical motion causes by a force that works on the $\mathrm{X}$ roll axis and yaw $\mathrm{Z}$. The stability analysis using these five methods yielded the conclusion that the longitudinal motion of the aircraft BWB AC 20.30 was asymptotically stable. We also use MATLAB R2013a to show the geometrical stability simulation of the system that yielded the same conclusion.
\end{abstract}

Keywords: stability of LTI system, longitudinal wave, (UAV) BWB AC 20.30.

e-ISSN: 2686-0341 p-ISSN: 2338-0896 


\section{Pendahuluan}

Beberapa tahun terakhir dunia penerbangan telah berkembang dengan sangat pesat, ditandai dengan terciptanya kendaraan udara tanpa awak. Kendaran udara jenis ini biasanya dinamai dengan Unmanned Aerial Vehicle (UAV). Salah satunya adalah pesawat terbang BWB AC 20.30. Pesawat ini merupakan satu jenis UAV rancangan University of Munich dan Hamburg University of Applied Sciences yang berkolaborasi dengan produsen pesawat Airbus. Model UAV BWB AC 20.30 didesain tanpa bagian tubuh utama pesawat (fuselage) maupun ekor Horizintal Tail Plane (HTP) sebagaimana lazimnya pada pesawat terbang berpenumpang [1].

Pada umumnya terdapat enam gerakan pada sistem pesawat terbang. Gerak ini meliputi gerak translasi dan gerak rotasi yang masing-masing berjumlah tiga gerakan terhadap posisi sumbu roll $\mathrm{X}$, pitch $Y$, dan yaw Z. Sedangkan gerak longitudinal merupakan gerakan yang disebabkan oleh gaya yang bekerja di bagian sumbu roll $X$ dan yaw $Z$ [2]. Terdapat dua mode gerak dalam gerak longitudinal pesawat terbang yaitu gerak phugoid mode dan gerak short period mode. Gerak phugoid mode merupakan gerak osilasi panjang akibat pengaruh sudut ketinggian maupun kendali gerak translasi pada sumbu roll $\mathrm{X}$, sedangkan gerak short period mode merupakan gerak osilasi pendek akibat pengaruh sudut serang maupun kendali gerak translasi pada sumbu yaw $Z$.

Pada dunia penerbangan kestabilan gerak pesawat terbang sangatlah penting agar pesawat bisa terbang dengan baik. [3] mengakatan bahwa sebuah sistem dikatakan stabil jika sistem tersebut tidak mengalami perubahan state seiring dengan berubahnya waktu. Pada artikel ini akan dianalisis kestabilan sistem gerak longitudinal pesawat terbang BWB AC 20.30 dengan memakai lima metode, yaitu RouthHurwitz, Lyapunov, metode nilai eigen, linearisasi dan metode input/output. Berikutnya, dilakukan simulasi stabilisasi gerak longitudinal pada pesawat terbang BWB AC 20.30 menggunakan piranti MATLAB R2013a.

Analisis kestabilan pada sistem yang serupa telah dilakukan oleh [4], akan tetapi hanya terbatas pada metode nilai eigen dan Routh-Hurwitz. Dalam artikel ini, penulis akan melengkapi analisis yang telah dilakukan oleh [4] dengan menambahkan metode metode Lyapunov, metode linearisasi serta metode input-output [5]. Analisis kestabilan model pesawat UAV lain, yaitu Elang Avionik yang merupakan pesawat pemantauan dan pemotretan udara telah dibahas oleh [6]. Sedangkan analisis kestabilan untuk sistem yang lain yang telah diteliti diantaranya adalah sistem dinamik satelit pengamat bumi [7], sistem underdamped pada tabrakan kendaraan [8], model penyebaran populasi perokok [9], dan model interaksi dua pemangsa-satu mangsa [10].

\section{Metode}

Setidaknya terdapat lima metode analisis kestabilan dari suatu sistem linear time invariant (LTI), yaitu metode nilai eigen, metode Routh-Hurwitz, metode Lyapunov, metode linearisasi serta metode input-output.

\section{Metode Nilai Eigen}

Secara umum konsep kestabilan nilai eigen digunakan untuk sistem yang memiliki orde rendah. Hal tersebut bertujuan untuk mempermudah dalam mencari nilai eigen.

Teorema 1. [11] Diberikan sebuah sistem persamaan 


$$
\dot{x}=A x,
$$

dengan A adalah suatu matriks berukuran $n \times n$ dengan $\lambda_{1}, \lambda_{2}, \ldots, \lambda_{k}$ dan $k \leq n$. adalah nilai eigen yang berbeda dari $A$.

1. Titik ekuilibrium $\tilde{x}=0$ disebut stabil asimtotik jika dan hanya jika $\operatorname{Re}\left(\lambda_{i}\right)<0$ untuk setiap $i=1,2, \ldots, k$.

2. Titik ekuilibrium $\tilde{x}=0$ disebut stabil jika dan hanyajika $\operatorname{Re}\left(\lambda_{i}\right)<0$ untuk setiap $i=1,2, \ldots, k$, dan jika ada nilai eigen $\lambda_{i}$ yang terletak di sumbu imajiner maka multiplisitas aljabar harus sama dengan multiplisitas geometri untuk nilai eigen tersebut.

3. Titik ekuilibrium $\tilde{x}=0$ disebut tidak stabil jika dan hanya jika $\operatorname{Re}\left(\lambda_{i}\right)>0$ untuk suatu $i=1,2, \ldots, k$, atau jika terdapat nilai eigen $\lambda_{i}$ di sumbu imajiner yang memiliki multiplisitas aljabar lebih besar dari pada multiplisitas geometrinya.

Kestabilan titik ekuilibrium erat hubungannya dengan kestabilan suatu sistem. Definisi berikut akan menjelaskan tentang hubungan antar keduanya.

Definisi 1. [12] Diberikan sistem LTI (1) dengan nilai awal $x(0)=x_{0}$.

1. Sistem (1) dikatakan stabil jika titik ekuilibrium $\tilde{x}=0$ merupakan titik ekuilibrium yang stabil.

2. Sistem (1) dikatakan stabil asimtotik jika titik ekuilibrium $\tilde{x}=0$ merupakan titik ekuilibrium yang stabil asimtotik.

3. Sistem (1) dikatakan tidak stabil jika titik ekuilibrium $\tilde{x}=0$ adalah titik ekuilibrium yang tidak stabil.

\section{Metode Routh-Hurwitz}

Metode Routh Hurwith tidak memerlukan data akar-akar persamaan karakteristik dari sistem, sehingga sistem yang memiliki orde tinggi lebih mudah menggunakan metode ini.

Diberikan fungsi polinomial $P(\xi) \in R[\xi]$, dengan

$$
P(\xi)=P_{0}+P_{1} \xi+\ldots+P_{n-1} \xi^{n-1}+P_{n} \xi^{n}
$$

dengan $P_{0}, P_{1}, \ldots, P_{n} \in R$ dan $R[\xi]$ adalah himpunan semua polinomial dalam $\xi$. Diasumsikan derajat dari $P(\xi)$ adalah $n$, maka jelas bahwa $P_{n} \neq 0$. Selanjutnya, akan dicari $P_{0}, P_{1}, \ldots, P_{n-1}, P_{n}$ untuk $P(\xi)$ agar dapat dikatakan Hurwitz. Diasumsikan bahwa $P_{n}>0$ atau jika $P_{n}<0$ maka dapat diselesaikan menggunakan polinomial $-P(\xi)$. Untuk menganalisis $P(\xi)$ adalah Hurwitz, dapat dilakukan dengan 2 uji yang ekuivalen yaitu uji Hurwitz dan uji Routh. 


\section{Uji Routh}

Uji Routh bermanfaat untuk menentukan jumlah akar-akar yang tidak stabil. Untuk menyatakan Uji Routh, berikut adalah pola yang digunakan untuk membentuk urutan ke $j$ yang terbentuk dari urutan ke $j$ -1 dan $j-2$ dengan $j=3, \ldots, n$.

$$
\begin{array}{rrrrr}
\text { urutan } j-2: a_{1} & a_{2} & a_{3} & \cdots \\
\text { urutan } j-1: b_{1} & b_{2} & b_{3} & \cdots \\
\text { urutan } j \quad: c_{1} & c_{2} & c_{3} & \cdots
\end{array}
$$

Nilai $c_{k}$ dengan $k=1,2, \ldots, n$, diperoleh dari negatif determinan matriks $2 \times 2$. Matriks tersebut terbentuk dari entri kolom pertama dan entri kolom ke $k+1$ pada urutan ke $j-2$ dan $j-1$,

$$
c_{k}=-\operatorname{det}\left[\begin{array}{ll}
a_{1} & a_{k+1} \\
b_{1} & b_{k+1}
\end{array}\right]=-\left(a_{1} b_{k+1}-b_{1} a_{k+1}\right)=b_{1} a_{k+1}-a_{1} b_{k+1} .
$$

Tabel Routh terbentuk dari koefisien-koefisien dari Persamaan Polinomial (2). Elemen dari urutan 1 dan urutan 2 pada Uji Routh dibentuk dari urutan genap dan ganjil dari masing-masing koefisien pada fungsi polinomial $P(\xi)$.

$$
\begin{array}{lllll}
\text { baris } & 1=P_{0} & P_{2} & P_{4} & \cdots \\
\text { baris } & 2=P_{1} & P_{3} & P_{5} & \cdots
\end{array}
$$

Jika ada koefisien di luar $\xi^{n}$ maka nilai koefisien tersebut adalah nol. Setelah terbentuk baris 1 dan baris 2 , kemudian dibentuk baris selanjutnya dengan menggunakan pola yang telah dijelaskan pada Persamaan (3). Sehingga diperoleh tabel Routh berikut

$$
\begin{array}{cccc}
P_{0} & P_{2} & P_{4} & \cdots \\
P_{1} & P_{3} & P_{5} & \cdots \\
c_{1} & c_{2} & c_{3} & \cdots \\
d_{1} & d_{2} & d_{3} & \cdots
\end{array}
$$

Susunan elemen-elemen kolom pertama tabel Routh disebut susunan Routh (Routh array), atau sering ditulis dengan $\left(r_{0}, r_{1}, r_{2}, \ldots, r_{n}\right)$.

Berikut adalah teorema Uji Routh yang digunakan untuk memudahkan dalam mengkarakterisasi polinomial $P(\xi)$.

Teorema 2. [5] Diasumsikan $P_{n}>0$. Maka Polinomial $P(\xi)$ memiliki semua akar dengan bagian real negatif jika dan hanya jika $r_{0}>0, r_{1}>0, \ldots, r_{n}>0$ yaitu susunan Routh memiliki elemen yang semuanya positif. 


\section{Uji Hurwitz}

Uji Hurwitz dapat mengetahui kestabilan sistem tanpa harus mengetahui nilai dari akar polinomial $P(\xi)$ dan jumlah akar yang bagian realnya bernilai positif. Diberikan matriks Hurwitz $H \in R^{n \times n}$ yang terbentuk dari koefisien-koefisien polinomial $P(\xi)$ sebagai berikut

$$
H=\left[\begin{array}{cccccccccc}
P_{1} & P_{0} & 0 & 0 & 0 & 0 & \ldots & 0 & 0 & 0 \\
P_{3} & P_{2} & P_{1} & P_{0} & 0 & 0 & \ldots & 0 & 0 & 0 \\
P_{5} & P_{4} & P_{3} & P_{2} & P_{1} & P_{0} & \ldots & 0 & 0 & 0 \\
\ldots & \ldots & \ldots & \ldots & \ldots & \ldots & \ldots & \ldots & \ldots & \ldots \\
\vdots & \vdots & \vdots & \vdots & \vdots & \vdots & \ldots & \vdots & \vdots & \vdots \\
P_{n-2} & P_{n-3} & P_{n-4} & P_{n-5} & P_{n-6} & P_{n-7} & \ldots & P_{0} & 0 & 0 \\
P_{n} & P_{n-1} & P_{n-2} & P_{n-3} & P_{n-4} & P_{n-5} & \ldots & P_{2} & P_{1} & P_{0}
\end{array}\right] .
$$

Selanjutnya, diberikan $\Delta_{1}, \Delta_{2}, \ldots, \Delta_{n-1}, \Delta_{n}$ yang merupakan notasi dari the leading principical minor dari Matriks $H$. The leading principical minor adalah determinan dari submatriks yang dibentuk dengan mengambil $k$ baris pertama dan $k$ kolom pertama yang sama. The leading principical minor $\Delta_{1}, \Delta_{2}, \ldots, \Delta_{n-1}, \Delta_{n}$ disebut determinan Hurwitz yang terbentuk dari polinomial $P(\xi)$.

Teorema 3. [5] Diasumsikan $P_{n}>0$. Maka, semua akar polinomial $P(\xi)$ memiliki bilangan real negatif jika dan hanya jika setiap determianan Hurwitz $\Delta_{1}>0, \Delta_{2}>0, \ldots, \Delta_{n-1}>0, \Delta_{n}>0$ bernilai positif.

\section{Metode Lyapunov}

Metode Lyapunov mendasarkan pada sebuah fungsi yang kontinu dan terdiferensial $V: R^{n} \rightarrow R$ yang merupakan suatu fungsi jarak yang diperumum dari titik tetap $x_{0}=0$. Menurut Polderman dan Willems (1997), jika fungsi skalar $V(x)$ memiliki sifat bahwa turunannya di setiap solusi dari sistem adalah negatif, maka fungsi $V$ disebut dengan fungsi Lyapunov. Turunan $V$ berbentuk kuadrat dalam sistem

$$
\frac{d}{d t} x=A x
$$

dapat diperoleh dari perhitungan berikut. Diberikan $x: R \rightarrow R^{n}$ memenuhi Persamaan (5), dan diberikan bentuk kuadarat

$$
V(x)=x^{T} P x
$$

dengan $V$ adalah fungsi skalar, $x$ adalah vektor keadaan, $x^{T}$ adalah transpose dari vektor $x$ dan $P$ adalah matriks simetris dengan $P=P^{T}$. Turunan $V(x)$ diperoleh dengan menggunakan aturan rantai diferensial berikut 


$$
\frac{d}{d t} V(x(t))=\dot{x}^{T} P x+x^{T} P \dot{x}+x^{T} \dot{P} x
$$

Notasi $\frac{d}{d t} V(x(t))$ pada pembahasan selanjutnya dilambangkan dengan $\dot{V}(x)$. Jika persamaan keadaan dibentuk pada sistem linear (1) maka Persamaan (6) menjadi

$$
\begin{aligned}
\dot{V}(x) & =(A x)^{T} P x+x^{T} P(A x)+x^{T} \dot{P} x \\
& =x^{T} A^{T} P x+x^{T} P A x+x^{T} \dot{P} x \\
& =x^{T}\left(A^{T} P+P A+\dot{P}\right) x .
\end{aligned}
$$

Matriks $P$ adalah konstan sehingga $\dot{P}=0$. Fakta tersebut mengakibatkan Persamaan (7) menjadi

$$
\dot{V}(x)=x^{T}\left(A^{T} P+P A\right) x .
$$

Jika $x(t)=a$ maka turunan dari $V(x(t))$ pada waktu $t$ adalah $a^{T}\left(A^{T} P+P A\right) a$. Diberikan

$$
Q=\left(A^{T} P+P A\right)
$$

maka Persamaan (8) menjadi

$$
\dot{V}(x)=x^{T} Q x
$$

Persamaan (9) disebut fungsi energi atau sering disebut juga sebagai fungsi Lyapunov [13].

Kestabilan sistem $\frac{d}{d t} x=A x$ dapat ditentukan dengan memanfaatkan persamaan Lyapunov (9) yang dijelaskan pada teorema berikut.

Teorema 4. [5] Diberikan Sistem (5) dan diasumsikan bahwa $A, P=P^{T}$ dan $Q=Q^{T}$ memenuhi persamaan Lyapunov (9). Maka,

1. jika $P>0, Q \leq 0$, dan $(A, Q)$ teramati maka sistem (5) stabil asimtotik,

2. jika $(P>0, Q \leq 0)$ maka sistem (5) stabil,

3. jika $P<0, Q \leq 0$, dan $(A, Q)$ teramati maka sistem (5) tidak stabil.

\section{Metode Linearisasi}

Metode ini digunakan untuk menentukan kestabilan sistem nonlinear. Melalui proses linearisasi akan diperoleh persamaan sistem yang linear di sekitar titik ekuilibriumnya. Pada dasarnya solusi kesetimbangan sistem non linear sama dengan kesetimbangan pada sistem linear [14].

Diberikan sistem berikut

$$
\frac{d}{d t} x=f(x)
$$

dengan $f: R^{n} \rightarrow R$ tidak linear, dan diasumsikan fungsi tersebut diferensiabel.

Teorema 5. [5] Diberikan bentuk linearisasi dari Sistem (11) yaitu 


$$
\frac{d}{d x} x=f^{\prime}(x) x
$$

dengan $f^{\prime}$ merupakan matriks jacobian dari matriks $f$ dan diasumsikan bahwa $f^{\prime}(\tilde{x})=0$, maka pernyataan berikut adalah benar.

1. Jika matriks $f^{\prime}(\tilde{x})$ mempunyai nilai eigen dengan bagian real negatif semuanya, maka titik ekuilibrium $\tilde{\boldsymbol{x}}$ disebut stabil asimtotik.

2. Jika setidaknya ada satu nilai eigen dari matriks $f^{\prime}(\tilde{x})$ memiliki bagian real positif, maka titik ekuilibrium $\tilde{\boldsymbol{x}}$ disebut tidak stabil.

\section{Metode Input/Output}

Sistem input-output diterapkan dalam sistem kontrol, dimana input dipilih sedemikian sehingga sistem menunjukkan kinerja yang memuaskan. Karakterisasi kestabilan metode ini dipaparkan dalam teorema berikut.

Teorema 6. [15], [16] Diberikan Sistem

$$
\left\{\begin{array}{l}
\dot{x}(t)=A x(t)+B u(t), \text { dengan } x(0)=0 \\
y(t)=C x(t)+D u(t) .
\end{array}\right.
$$

yang merupakan realisasi minimal, maka Sistem (13) stabil secara eksternal jika dan hanya jika A merupakan matriks yang stabil.

\section{Hasil dan Diskusi}

\section{Model Dinamik Gerak Longitudinal Pesawat Terbang BWB AC 20.30}

Gerak longitudinal menjelaskan gerak vertikal pesawat udara sebagai akibat dari gaya di sumbu roll $\mathrm{X}$ dan yaw $\mathrm{Z}$, misalnya gerak pesawat menukik dan mendaki. Arah gerak pesawat berbasis tiga sumbu yang dimilikinya disajikan dalam Gambar 1 berikut.

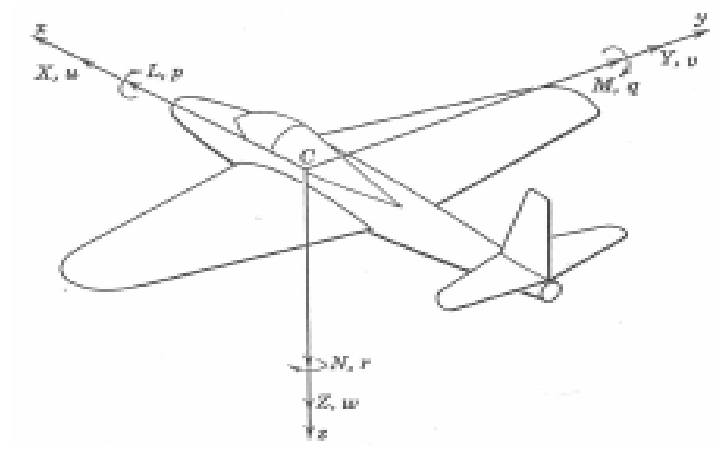

Gambar 1. Bodi pesawat terbang BWB AC 20.30 dan arah geraknya

Sedangkan komponen arah sumbu badan pesawat terinci dalam tabel 1 berikut ini. 
Tabel 1. Arah Sumbu Badan

\begin{tabular}{lccc}
\hline & Sumbu Roll X & Sumbu pitch Y & Sumbu yaw Z \\
\hline Kontrol gerak rotasi & $p$ & $q$ & $r$ \\
Kontrol gerak translasi & $u$ & $v$ & $w$ \\
Gaya aerodinamika & $A$ & $B$ & $C$ \\
Momen aerodinamika & $L$ & $M$ & $N$ \\
Perubahan sudut & $\phi$ & $\theta$ & $\psi$ \\
\hline
\end{tabular}

Gerak longitudinal diperoleh dengan memodelkan gerak rotasi dan gerak translasi pada pesawat terbang. Gerak translasi adalah gerakan benda bergeser pada suatu lintasan dengan di setiap titiknya mempunyai bentuk yang sama, atau dapat dikatakan gerak translasi dilakukan oleh sebuah benda jika panjang lintasan yang ditempuh oleh benda tersebut selalu sama di setiap titiknya. Sedangkan gerak rotasi merupakan pergerakan sebuah benda membentuk lintasan berupa lingkaran di setiap titiknya [17]. Gerak longitudinal pesawat dikatakan stabil jika posisi pesawat sesuai dengan yang diatur oleh pengemudi.

Rumus gerak translasi pesawat terbang BWB AC 20.30 di sumbu $(X, Y, Z)$ dinyatakan oleh persamaan berikut [1]

$$
\begin{aligned}
& A=m(\dot{u}+q w-v r+g \sin \theta), \\
& B=m(\dot{v}+u r-p w+g \cos \theta \sin \phi), \\
& C=m(\dot{w}+p v-u q+g \cos \theta \cos \phi) .
\end{aligned}
$$

Sedangkan model matematika gerak rotasinya di sumbu $(X, Y, Z)$ dinyatakan oleh persamaan berikut [1]

$$
\begin{aligned}
& L=I_{x x} \dot{p}-I_{x z}(\dot{r}+p q)+\left(I_{z z}-I_{y y}\right) q r, \\
& M=I_{y y} \dot{q}+I_{x z}\left(p^{2}-r^{2}\right)+\left(I_{x x}-I_{z z}\right) p r, \\
& N=I_{z z} \dot{r}-I_{x z}(\dot{p}-q r)+\left(I_{y y}-I_{z y}\right) p q .
\end{aligned}
$$

Berdasarkan model nonlinear pada Persamaan (14) dan Persamaan (15) diperoleh bentuk sistem persamaan autonomous "gerak longitudinal pesawat terbang BWB AC 20.30" sebagai berikut

$$
\begin{aligned}
\dot{u} & =\frac{-m q w+m v r-m g \sin \theta+A}{m} \\
\dot{w} & =\frac{-m p v+m u q-m g \cos \theta \sin \phi+C}{m} \\
\dot{q} & =\frac{-I_{x z} p^{2}+I_{x z} r^{2}-I_{x x} p r+I_{z z} p r+M}{I_{y y}} \\
\dot{\theta} & =q .
\end{aligned}
$$

Jika $(x)=(u, w, q, \theta)$, maka bentuk sistem persamaan autonomous (16) dapat ditulis sebagai berikut 


$$
\dot{x}=f(x)=\left(\begin{array}{c}
\dot{u} \\
\dot{w} \\
\dot{q} \\
\dot{\theta}
\end{array}\right)=\left(\begin{array}{c}
\frac{-m q w+m v r-m g \sin \theta+A}{m} \\
\frac{-m p v+m u q-m g \cos \theta \sin \phi+C}{m} \\
\frac{-I_{x z} p^{2}+I_{x z} r^{2}-I_{x x} p r+I_{z z} p r+M}{I_{y y}} \\
q
\end{array}\right),
$$

sehingga jika $f(x)=\left(\begin{array}{c}f_{1}(x) \\ f_{2}(x) \\ f_{3}(x) \\ f_{4}(x)\end{array}\right)$, maka

$$
\begin{aligned}
& f_{1}(x)=\frac{-m q w+m v r-m g \sin \theta+A}{m} \\
& f_{2}(x)=\frac{-m p v+m u q-m g \cos \theta \sin \phi+C}{m} \\
& f_{3}(x)=\frac{-I_{x z} p^{2}+I_{x z} r^{2}-I_{x x} p r+I_{z z} p r+M}{I_{y y}} \\
& f_{4}(x)=q .
\end{aligned}
$$

Berdasarkan persamaan (17) dapat ditentukan titik ekuilibrium dari "gerak longitudinal pesawat terbang BWB AC 20.30" yaitu $(\tilde{x})=(\tilde{u}, \tilde{w}, \tilde{q}, \tilde{\theta})=\left(0,0,0, \arcsin \left(\left(v r+\frac{1}{m} A\right) \frac{1}{g}\right)\right)$. Adapun hasil linearisasi dari Persamaan (14) dan Persamaan (15) dapat direpresentasikan dalam persamaan state space berikut

$$
\begin{aligned}
& \dot{x}=A x+B u \\
& {\left[\begin{array}{c}
\Delta \dot{u} \\
\Delta \dot{w} \\
\Delta \dot{q} \\
\Delta \dot{\theta}
\end{array}\right]=\left[\begin{array}{cccc}
\frac{A_{u}}{m} & \frac{A_{w}}{m} & 0 & -g \\
\frac{C_{u}}{m} & \frac{C_{w}}{m} & U_{0} & 0 \\
\tilde{M}_{u} & \tilde{M}_{w} & \tilde{M}_{q} & 0 \\
0 & 0 & 1 & 0
\end{array}\right]\left[\begin{array}{c}
\Delta u \\
\Delta w \\
\Delta q \\
\Delta \theta
\end{array}\right]+\left[\begin{array}{ccc}
\frac{A_{E}}{m} & \frac{A_{\delta_{F W i n g}}}{m} & \frac{A_{F \operatorname{Re} \text { arEnd }}}{m} \\
\frac{C_{E}}{m} & \frac{C_{\delta_{F W i n g}}}{m} & \frac{C_{\delta_{F \operatorname{Re}} \text { arEnd }}}{m} \\
\tilde{M}_{\delta_{E}} & \tilde{M}_{\delta_{F W i n g}} & \tilde{M}_{\delta_{F \operatorname{Re} \text { arEnd }}} \\
0 & 0 & 0
\end{array}\right]\left[\begin{array}{c}
\Delta \delta_{E} \\
\Delta \delta_{F W i n g} \\
\Delta \delta_{F \operatorname{Re} \text { arEnd }}
\end{array}\right] } \\
& y=C x=\left[\begin{array}{cccc}
1 & 0 & 0 & 0 \\
0 & 1 & 0 & 0 \\
0 & 0 & 1 & 0 \\
0 & 0 & 0 & 1
\end{array}\right]\left[\begin{array}{c}
\Delta u \\
\Delta w \\
\Delta q \\
\Delta \theta
\end{array}\right] .
\end{aligned}
$$


Matriks $A$ dan Matriks $B$ merupakan parameter aerodinamika dari persawat terbang BWB AC 20.30. Pengambilan estimasi parameter aerodinamika tersebut diperoleh melalui uji cerobong angin (wind tunnel) di Dresden [1].

Tabel 2 Nilai Parameter Aerodinamika Matriks $A$, dalam satuan detik (s) dan meter $(\mathrm{m})$

\begin{tabular}{cc}
\hline Parameter Aerodinamika & Satuan \\
\hline$\frac{A_{\boldsymbol{u}}}{m}$ & $-0.1037 \mathrm{~s}^{-1}$ \\
$\frac{A_{\boldsymbol{w}}}{m}$ & $-0.8824 \mathrm{~s}^{-1}$ \\
$g$ & $9.81 \mathrm{~ms}^{-1}$ \\
$\frac{C_{\boldsymbol{u}}}{m}$ & $-0.6984 \mathrm{~s}^{-1}$ \\
$\frac{C_{w}}{m}$ & $-5.1478 \mathrm{~s}^{-1}$ \\
$\tilde{\boldsymbol{M}}_{\boldsymbol{u}}$ & $0.2188 \mathrm{~m}^{-1} \mathrm{~s}^{-1}$ \\
$\tilde{M}_{w}$ & $-0.7572 \mathrm{~m}^{-1} \mathrm{~s}^{-1}$ \\
$\tilde{M}_{q}$ & $0.2188 \mathrm{~s}^{-1}$ \\
\hline
\end{tabular}

Tabel 3 Nilai Parameter Aerodinamika Matriks B, dalam satuan detik (s), meter (m) dan radian (rad)

\begin{tabular}{|c|c|}
\hline Parameter Aerodinamika & Satuan \\
\hline$\frac{A_{\delta_{E}}}{m}$ & $-0.1769 \mathrm{~m} \cdot \mathrm{rad}^{-1} \mathrm{~s}^{-2}$ \\
\hline$\frac{C_{\delta_{E}}}{m}$ & $-13.4383 \mathrm{~m} \cdot \mathrm{rad}^{-1} \mathrm{~s}^{-2}$ \\
\hline$\tilde{M}_{\delta_{E}}$ & $-20.9719 \mathrm{rad}^{-1} \mathrm{~s}^{-2}$ \\
\hline$\frac{A_{\delta_{F W i n g}}}{m}$ & $-0.9938 \mathrm{~m} \cdot \mathrm{rad}^{-1}{ }_{\mathrm{s}}^{-2}$ \\
\hline$\frac{C_{\delta_{F W i n g}}}{m}$ & $-12.1762 \mathrm{~m} \cdot \mathrm{rad}^{-1}{ }_{s}^{-2}$ \\
\hline$\tilde{M}_{\delta_{F W i n g}}$ & $-6.6118 \mathrm{rad}^{-1}{ }_{\mathrm{s}}^{-2}$ \\
\hline$\frac{A_{\delta_{\text {FRearFnd }}}}{m}$ & $-1.0798 \mathrm{~m} \cdot \mathrm{rad}^{-1}{ }_{\mathrm{s}}^{-2}$ \\
\hline
\end{tabular}




\begin{tabular}{cc}
\hline Parameter Aerodinamika & Satuan \\
\hline$\frac{C_{\delta_{\text {FRearEnd }}}^{m}}{m}$ & $-18.6711 \mathrm{~m} \cdot \mathrm{rad}^{-1}-2$ \\
$\tilde{M}_{\delta_{\text {FRearEnd }}}$ & $-11.6014 \mathrm{rad}^{-1}-2$ \\
\hline
\end{tabular}

Dengan mensubsitusikan nilai parameter Matriks $A$ dan Matriks $B$ pada Tabel 2 dan Tabel 3, maka diperoleh persamaan state space sebagai berikut.

$$
\begin{aligned}
\dot{x} & =\left[\begin{array}{cccc}
-0.1037 & -0.8824 & 0 & -9.81 \\
-0.6984 & -5.1478 & 20 & 0 \\
0.2188 & -0.7572 & -2.81 \cdot 10^{-5} & 0 \\
0 & 0 & 1 & 0
\end{array}\right] x+\left[\begin{array}{ccc}
-0.1769 & -0.9938 & -1.0798 \\
-13.4283 & -12.1762 & -18.6711 \\
-20.9719 & -6.188 & -11.6014 \\
0 & 0 & 0
\end{array}\right] u \\
y & =\left[\begin{array}{llll}
1 & 0 & 0 & 0 \\
0 & 1 & 0 & 0 \\
0 & 0 & 1 & 0 \\
0 & 0 & 0 & 1
\end{array}\right] x .
\end{aligned}
$$

\section{Aplikasi Teori Kestabilan pada Gerak Longitudinal Pesawat Terbang BWB AC 20.30}

Konsep kestabilan merupakan salah satu hal terpenting yang diperhatikan pada penerbangan (tidak hanya penerbangan, tetapi pada sistem secara keseluruhan), karena jika pesawat tidak stabil maka ketika pesawat yang sedang terbang lurus dan mendapatkan gangguan akan berakibat pesawat bergerak memutar. jika sistem dinamik pesawat stabil maka posisi pesawat akan setimbang kembali. Bagian ini menjelaskan tentang kestabilan gerak longitudinal pesawat terbang BWB AC 20.30 menggunakan berbagai metode.

\section{Metode Nilai Eigen}

Persamaan karakteristik dari sistem (19) adalah

$$
P(\lambda)=\lambda^{4}+5.2515 \lambda^{3}+15.0617 \lambda^{2}+7.5782 \lambda+16.2372 .
$$

Dengan menggunakan bantuan software MATLAB R2013a, didapat nilai-nilai eigen atau akar-akar karakteristik dari persamaan (20) adalah

$$
\begin{aligned}
& \lambda_{1}=-2.5768+2.5885 i, \\
& \lambda_{2}=-2.5768-3.5885 i, \\
& \lambda_{3}=-0.0489+1.1022 i, \text { dan } \\
& \lambda_{4}=-0.0489-1.1022 i .
\end{aligned}
$$

Nilai eigen di atas memiliki bagian real yang semuanya negatif, sehingga menurut Teorema 1 diperoleh kesimpulan bahwa sistem persamaan gerak longitudinal pesawat terbang BWB AC 20.30 merupakan sistem yang stabil asimtotik. Sehingga posisi pesawat telah sesuai dengan yang diatur oleh pengemudi/pengendali. 


\section{Metode Routh-Hurwitz}

Uji Routh

Tabel Routh yang terbentuk dari Persamaan (19) sebagai berikut

$\begin{array}{lll}16.2372 & 15.0617 & 1 \\ 7.5782 & 5.2515 & 0 \\ 28.8709 & 7.5782 & \\ 94.1864 & 0 & \\ 713.7634 . & & \end{array}$

Terlihat bahwa semua elemen kolom pertama dari tabel Routh (susunan Routh) bernilai positif (tidak ada perubahan tanda). Menurut Teorema 2, hal tersebut menunjukkan bahwa semua akar Persamaan (20) memiliki bagian real negatif, artinya "sistem persamaan gerak longitudinal pesawat terbang BWB AC 20.30" stabil asimtotik. Hal ini berimplikasi pasa posisi pesawat yang telah sesuai dengan yang diatur oleh pengemudi/pengendali.

\section{Uji Hurwitz}

Matriks Hurwits $(H)$ yang dibentuk dari Persamaan (19) sebagai berikut

$$
H=\left[\begin{array}{cccccc}
7.5782 & 16.2372 & 0 & 0 & 0 & 0 \\
5.2515 & 15.0617 & 7.5782 & 16.2372 & 0 & 0 \\
0 & 1 & 5.2515 & 15.0617 & 7.5782 & 16.2372
\end{array}\right] .
$$

Determinan Hurwitz dari Matriks $H$ di atas yaitu

$$
\begin{aligned}
& \Delta_{1}=7.5782 \\
& \begin{aligned}
\Delta_{2} & =\left|\begin{array}{ll}
7.5782 & 16.2372 \\
5.2515 & 15.0617
\end{array}\right| \quad \Delta_{3}=\left|\begin{array}{ccc}
7.5782 & 16.2372 & 0 \\
5.2515 & 15.0617 & 7.5782 \\
0 & 1 & 5.2515
\end{array}\right| \\
& =28.8709
\end{aligned} \\
& =98.1865 \text {. }
\end{aligned}
$$

Determinan Hurwitz dari Matriks $H\left(\Delta_{1}, \Delta_{2}, \Delta_{3}\right)$ lebih besar dari nol. Menurut Teorema 3 (Uji Hurwitz), hal tersebut menunjukkan bahwa semua akar Persamaan (19) memiliki bilangan real negatif, artinya "sistem persamaan gerak longitudinal pesawat terbang BWB AC 20.30" stabil asimtotik. Sehingga posisi pesawat telah sesuai dengan yang diatur oleh pengemudi/pengendali.

\section{Metode Lyapunov}

Kestabilan titik ekuilibrium sistem dapat dianalisis dengan menggunakan Fungsi Lyapunov $V(x)=x^{T} P x$. Matriks $P$ dapat dicari dari Persamaan $Q=\left(A^{T} P+P A\right)$, dengan $Q$ merupakan sebarang matriks definit negatif. Selanjutnya, akan ditentukan Matriks simetris $P$. Misal diambil 


$$
Q=\left[\begin{array}{cccc}
-1 & 0 & 0 & 0 \\
0 & -1 & 0 & 0 \\
0 & 0 & -1 & 0 \\
0 & 0 & 0 & -1
\end{array}\right] \text { dan } P=\left[\begin{array}{cccc}
p_{11} & p_{12} & p_{13} & p_{14} \\
p_{12} & p_{22} & p_{23} & p_{24} \\
p_{13} & p_{23} & p_{33} & p_{34} \\
p_{14} & p_{24} & p_{34} & p_{44}
\end{array}\right] \text {. }
$$

Selanjutnya, matriks $P$ diperoleh dengan mensubsitusi Matriks $Q$, Matriks $A$, dan Matriks $A^{T}$ pada persamaan $Q=\left(A^{T} P+P A\right)$ dan dengan menggunakan aturan Cramer maka diperoleh matriks

$$
P=\left[\begin{array}{cccc}
119.9215 & -22.5965 & -17.5755 & 0.0510 \\
-22.5965 & 31.5712 & -187.6427 & -508.8943 \\
-17.5755 & -187.6427 & 1.4580 & 3.7524 \\
0.0510 & -508.8949 & 3.7524 & 1.0006
\end{array}\right] .
$$

Determinan submatriks atau sering disebut minor pokok/utama dari matrik $P$ yaitu

$$
\begin{aligned}
& \Delta_{1}=119.9215, \\
& \Delta_{2}=3.2755 \times 10^{3}, \\
& \Delta_{3}=3.9437 \times 10^{5}, \\
& \Delta_{4}=8.2671 \times 10^{7} .
\end{aligned}
$$

Penyelesaian di atas menjelaskan bahwa setiap determinan submatriks utama dari matriks $P$ bernilai positif. Berdasarkan Kriteria Sylvester, jika setiap determinan submatriks utama bernilai positif maka matriks simetris $P$ merupakan matriks definit positif sehingga $x^{T} P x>0$ untuk $x \neq 0$ [18]. Hal tersebut berakibat $V(x)=x^{T} P x>0$, dan karena $Q \leq 0$ maka $\dot{V}(x)=x^{T} Q x \leq 0$.

Berdasarkan Teorema 4, jika $Q \leq 0, P>0$, maka $(A, Q)$ dapat diamati, dan hal tersebut berarti sistem persamaan "gerak longitudinal pesawat terbang BWB AC 20.30" merupakan sistem yang stabil asimtotik yang berimplikasi pada posisi dan gerak pesawat yang telah sesuai dengan yang dikendalikan pengemudi.

\section{Metode Linearisasi}

Kestabilan Sistem (19) dengan metode linearisasi dapat diketahui dengan melihat bagian real dari nilai eigen martiks $A=f^{\prime}(\tilde{x})$. Diketahui

$$
A=\left[\begin{array}{cccc}
-0.1037 & -0.8824 & 0 & -9.81 \\
-0.6984 & -5.1478 & 20 & 0 \\
0.2188 & -0.7572 & -2.81 \cdot 10^{-5} & 0 \\
0 & 0 & 1 & 0
\end{array}\right] .
$$

Pada metode nilai eigen telah diketahui nilai eigen dari matriks $A=f^{\prime}(\tilde{x})$ sebagai berikut 


$$
\begin{aligned}
& \lambda_{1}=-2.5768+2.5885 i, \\
& \lambda_{2}=-2.5768-3.5885 i, \\
& \lambda_{3}=-0.0489+1.1022 i, \text { dan } \\
& \lambda_{4}=-0.0489-1.1022 i .
\end{aligned}
$$

Menurut Teorema 5, jika matriks $A=f^{\prime}(\tilde{x})$ memiliki nilai-nilai eigen dengan semua bagian real negatif, mengakibatkan titik ekuilibrium $\tilde{x}$ stabil asimtotik. Karena titik ekuilibriumnya stabil asimtotik, maka menurut Definisi 2 sistem tersebut juga stabil asimtotik.

\section{Metode Input/output}

Menurut Teorema 6, persamaan state space disebut stabil secara eksternal apabila $A$ merupakan matriks yang stabil. $A$ dikatakan matriks stabil jika $A$ adalah matriks Hurwitz. Artinya semua akar-akar polinomial dari matriks $A$ memiliki bagian real yang bernilai negatif. Pada persamaan (19) diperoleh matriks

$$
A=\left[\begin{array}{cccc}
-0.1037 & -0.8824 & 0 & -9.81 \\
-0.6984 & -5.1478 & 20 & 0 \\
0.2188 & -0.7572 & -2.81 \cdot 10^{-5} & 0 \\
0 & 0 & 1 & 0
\end{array}\right] .
$$

Pada analisis kestabilan dengan metode nilai eigen, telah diketahui bahwa semua akar-akar dari polinomial matriks $A$ memiliki bagian real yang bernilai negatif, yaitu

$$
\begin{aligned}
& \lambda_{1}=-2.5768+2.5885 i, \\
& \lambda_{2}=-2.5768-3.5885 i, \\
& \lambda_{3}=-0.0489+1.1022 i, \text { dan } \\
& \lambda_{4}=-0.0489-1.1022 i .
\end{aligned}
$$

Semua bagian real dari nilai eigen di atas bernilai negatif, artinya "sistem persamaan gerak longitudinal pesawat terbang BWB AC 20.30" stabil secara eksternal. Sehingga posisi pesawat telah sesuai dengan yang diatur oleh pengemudi/pengendali.

Menganalisis kestabilan sistem dapat dilakukan juga dengan menggunakan software MATLAB R2013a. Simulasi numerik ini dilakukan untuk memberikan gambaran secara geometris dari kestabilan suatu sistem. Terdapat dua mode gerak longitudinal pesawat terbang yaitu short period mode dan phugoid mode. Gerak short period mode merupakan gerak osilasi pendek. Karakteristik gerak short period mode pada pesawat terbang BWB AC 20.30 dapat disimulasikan dengan kontrol gerak translasi $(w)$ di sumbu yaw Z saat kondisi awal/initial condition tidak sama dengan nol $(w \neq 0)$ dan lebih besar dari nol $(w>0)$. Hal tersebut terjadi sebagai akibat dari defleksi input kendali pada bagian pesawat terbang BWB AC 20.30.

Sedangkan gerak phugoid mode (osilasi panjang) pada pesawat terbang mendapatkan pengaruh dari sudut ketinggian/pitch altitude $(\theta)$. Karakteristik gerak phugoid mode pada pesawat terbang BWB AC 
20.30 dapat disimulasikan dengan mengatur sudut ketinggian/pitch altitude $(\theta)$ pada pesawat terbang, dengan nilai $\theta \neq 0$ dan $\theta>0$.

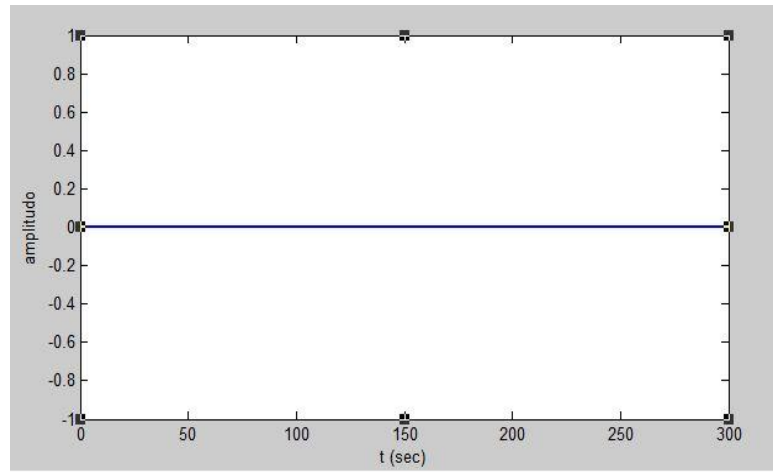

Gambar 2. Posisi sistem pesawat pada kondisi awal.

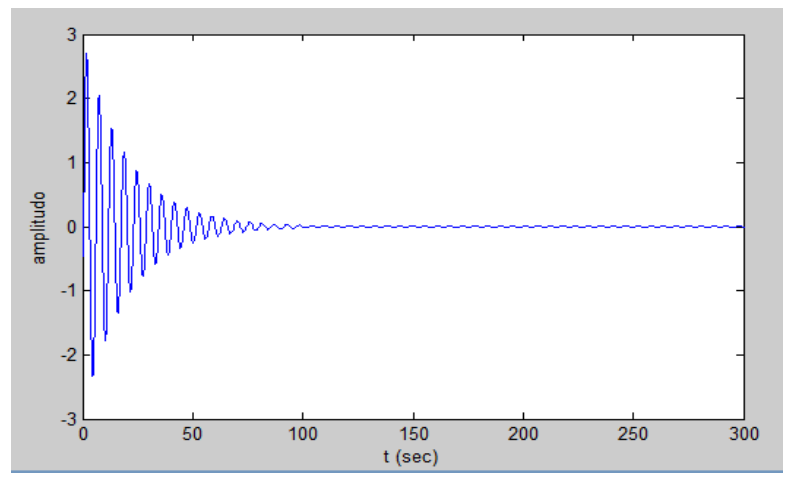

Gambar 3. Output short periode mode saat kondisi awal gerak translasi $w=5$ dan $t=0-300$ detik.

Gambar 2 merepresentasikan sistem pesawat saat kondisi awal sama dengan nol atau dapat dikatakan bahwa keempat variabel keadaan yaitu kontrol gerak translasi di $(u),(w)$, gerak rotasi di $(q)$ dan sudut ketinggian/pitch altitude $\theta$ bernilai nol. Hal tersebut dapat diartikan bahwa sistem gerak longitudinal pesawat terbang BWB AC 20.30 dalam kondisi diam.

Berdasarkan Gambar 3 terlihat bahwa dari keempat variabel keadaan yaitu kontrol gerak translasi di $u, w$, gerak rotasi $q$ dan sudut ketinggian (pitch altitude) $\theta$, yang sangat berpengaruh terhadap karakteristik terbang short period mode adalah gerak translasi di $(w)$ terhadap kondisi awal yang berubah yaitu tidak sama dengan nol.

Perubahan tersebut diakibatkan oleh defleksi input kendali yaitu Elevons $\left(\delta_{E}\right)$, Flap sayap $\left(\delta_{F}\right.$ Wing $)$, dan Flap rear end $\left(\delta_{F}\right.$ Rear End $)$. Gambar 3 menjelaskan saat kondisi awal gerak translasi $w=5$ dan $t=0-300$ detik, maka gerak short period mode pada pesawat terbang BWB AC 20.30 dalam kondisi stabil asimtotik. Hal tersebut terjadi karena pada saat waktu $t=0-300$ detik gerak short period mode pada pesawat terbang BWB AC 20.30 menuju kondisi trim/seimbang.

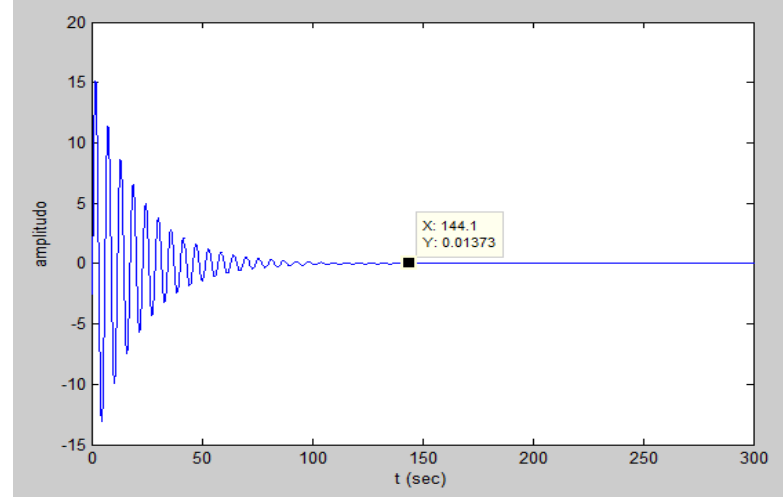

Gambar 4. Output short periode mode saat kondisi awal gerak translasi $w=28$ dan $t=0-300$ detik.

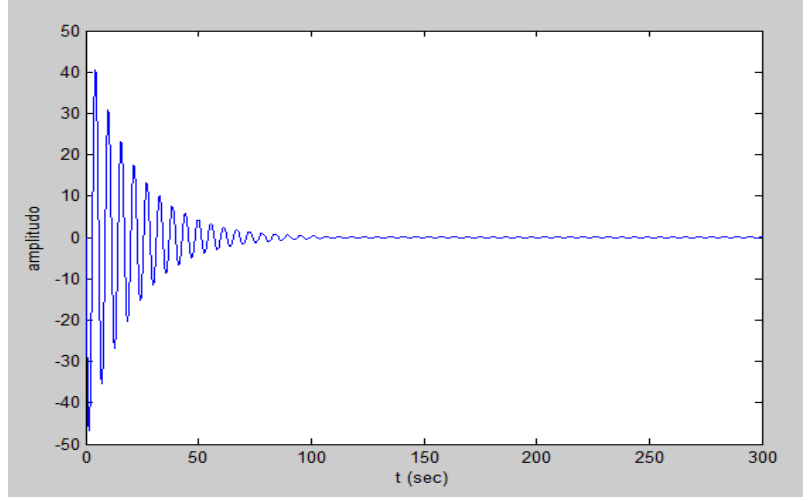

Gambar 5. Phugoid mode saat kondisi awal sudut ketinggian $\theta=5$ dan $t=0-300$ detik. 
Gambar 4 menggambarkan gerak short period mode pada saat kondisi awal gerak translasi $w=28$ dan $t=0-300$ detik, maka gerak short period mode tersebut menunjukkan kondisi stabil asimtotik. Saat waktu $t=144.1$ detik gerak short period mode pada pesawat terbang BWB AC 20.30 berada di kondisi trim/seimbang dengan nilai simpangan sebesar 0.01373 .

Pada penjelasan sebelumnya telah disebutkan bahwa dari keempat variabel keadaan yaitu kontrol gerak translasi di $(u),(w)$, gerak rotasi di $(q)$ dan sudut ketinggian/pitch altitude $\theta$ yang mempengaruhi gerak phugoid mode (osilasi panjang) pada pesawat terbang yaitu sudut ketinggian/pitch altitude $(\theta)$. Gambar 5 menjelaskan saat kondisi awal sudut ketinggian $\theta=5$ dan $t=0-300$ detik maka gerak phugoid mode (osilasi panjang) pada pesawat terbang berada pada posisi stabil asimtotik.

\section{Kesimpulan}

Hasil analisis stabilitas gerak longitudinal pesawat terbang BWB AC 20.30 menggunakan lima metode kestabilan yang berbeda menunjukkan bahwa sistem pesawat tersebut stabil asimtotik. Berdasarkan simulasi dapat disimpulkan bahwa gerak short period mode yaitu gerak translasi di sumbu yaw Z merupakan jenis gerak yang paling mempengaruhi stabilitas sistem tersebut. Model dinamik gerak longitudinal Pesawat Terbang BWB AC 20.30 yang disajikan dalam artikel ini masih menggunakan sistem linear time invariant (LTI) yang memiliki banyak keterbatasan.

Dalam penelitian selanjutnya, dinamika gerak pesawat dapat dimodelkan menggunakan sistem linear time varying (LTV) maupun linear parameter varying (LPV) yang akan menghasilkan model yang lebih akurat sehingga analisis kestabilannya pun juga akan lebih akurat. Selain itu pengembangan analisis kestabilan gerak pesawat juga dapat dilakukan dengan melibatkan unsur gangguan dan ketidakpastian yang ada sehingga lebih sesuai dengan kondisi dinamika gerak pesawat yang sesungguhnya.

\section{Ucapan Terima Kasih}

Penulis mengucapkan terima kasih kepada semua pihak yang telah memberikan dukungan baik moril maupun materiil sehingga penelitian ini dapat penulis selesaikan.

\section{Referensi}

[1] C. Neubacher, "Flight dynamic investigations of a blended wing body aircraft," Thesis dari Hamburg University of Applied Sciences, 2008, p 31 - 45.

[2] D. McLean, "Automatic flight control system", Penerbit Prentice Hall Inc, UK, 1990.

[3] H. D. Laksono, "Sistem kendali". Penerbit Graha Ilmu, Yogyakarta, 2014.

[4] M. Herlambang, "Analisis kestabilan titik equilibrium gerak longitudinal pesawat terbang bwb ac 20.30 menggunakan metode nilai eigen dan metode routh-hurwitz serta simulasinya menggunakan matlab simulink", Skripsi Jurusan Matematika UIN Sunan Kalijaga, 2015.

[5] J. W. Polderman and J. C. Willems, "Introduction to mathematical theory of system and control". Penerbit Spinger-Verlag, Berlin, 1997, p. 239 - 266.

[6] E. B. Purwanto, "Pemodelan sistem dan analisis kestabilan dinamik pesawat UAV," J. Teknol. Dirgant., 10:1-12, 2012.

[7] R. Octavia and Yusuf Fuad, "Analisis kestabilan sistem dinamik satelit pengamat bumi," 
MATHunesa J. Ilm. Mat., 3:158-165, 2017.

[8] S. I. N. Faizah and Y. Fuad, "Analisis kestabilan sistem dinamik underdamped pada tabrakan kendaraan," MATHunesa J. IIm. Mat., 3:87-94, 2017.

[9] R. Pomalingo, Resmawan, and Nurwan, "Analisis dinamik model matematika penyebaran populasi perokok," J. Mat. Integr., 15:111-119, 2019.

[10] Y. A. R. Langi, "Analisis kestabilan model interaksi dua pemangsa-satu mangsa dengan daya dukung lingkungan pada sistem mangsa," d'CARTESIAN, 2:50-57, 2013.

[11] G. J. Olsder and J. W. van der Woude, "Mathematical systems theory". Penerbit VVSD, Delft, 2004, p. 58.

[12] M. W. Musthofa, "Pengantar teori sistem dan kendali," Handout Kuliah, Yogyakarta, 2015, p 5759.

[13] E. Zerz, "Introduction to system and control theory". Kaiserslautern: Technische Universität Kaiserslautern, 2005, p. 49 - 50.

[14] S. Wiggins, "Introduction to applied nonlinear dynamical system and chaos". Penerbit SpringerVerlag, New York, 2000, p. 10-11.

[15] C. Heij, A. Ran, and F. van Schagen, "Introduction to matematical system teory linear system", Identification and Control, 1st ed. Basel, Penerbit Birkhauser Verlag, Switzerland, 2007, p. 43 - 45.

[16] A. Astolfi, "System and control theory, an introduction". Penerbit Department of Imperial College London, London, 2006, p. 25 - 56.

[17] P. Raharjo, "Gerak Dasar Pesawat Terbang," panggih15.wordpress.com, 2010. https://panggih15.wordpress.com/2010/02/17/gerak-dasar-pesawat-terbang/ (accessed Jun. 12, 2019).

[18] H. Anton, "Aljabar linear elementer", 5th ed. Penerbit Erlangga, Jakarta, 1987, p. 710. 